\title{
Nutrition and physiology of hybrid Eucalyptus urograndis in soil fertilized with sewage sludge
}

\author{
Alessandro Reinaldo Zabotto', Leticia Danielle Longuini Gomes', Caroline de Moura D'andréa Mateus², \\ Roberto Lyra Villas Boas², Shoey Kanashiro', Armando Reis Tavares ${ }^{3 *}$
}

${ }^{1}$ Instituto de Botânica, Av. Miguel Stefano, 3687, São Paulo, SP, Brazil, “Universidade Estadual Paulista "Júlio de Mesquita Filho" (UNESP), Av. Universitária, 3780, Botucatu, SP, Brazil, ${ }^{3}$ nstituto Agronômico de Campinas, Avenida Luiz Pereira dos Santos, 1.500, Jundiai, SP, Brazil

\section{A B S T R A C T}

Sewage sludge is a residual pollutant product from the treatment of urban effluent and must be adequately processed before final disposal in order to avoid environmental contamination. The use of sewage sludge in agricultural and forestry areas can improve the physical, chemical and biological properties of soil; it can also be a source of nutrients, increasing crop productivity. Accordingly, this study aimed to evaluate the growth and development of hybrid Eucalyptus urograndis (Eucalyptus grandis x E. urophylla) seedlings cultivated in soil with different doses of sewage sludge. To accomplish this, hybrid $E$. urograndis seedlings were cultivated for 120 days in pots containing soil (dystrophic Red-Yellow Latosol -LVA) with different doses of sewage sludge (0, 30, 60 or $90 \mathrm{Mg}^{-1}$ ). The experiment was carried out in a randomized complete block design consisting of four treatments, three replications with four plants per replication, totaling 48 plants. Biometric, biomass and physiological variables (chlorophyll, gaseous exchange, stomatal conductance and transpiration); in addition to macro- and micronutrient contents in leaves and soils of each treatment were evaluated. The treatments with sewage sludge were statistically superior to control treatment for all variables. Therefore, we recommend the application of $60 \mathrm{Mg} \mathrm{ha}^{-1}$ sewage sludge for the growth of hybrid Eucalyptus urograndis seedlings. Conversely, $90 \mathrm{Mg} \mathrm{ha}^{-1}$ sewage sludge inhibited hybrid E. urograndis root growth. Moreover, the use of sewage sludge as organic fertilizer in tropical soils is a viable and sustainable alternative for Eucalyptus cultivation.

Keywords: Biosolid; Eucalyptus; Fertilization; Organic nutrition

\section{INTRODUCTION}

The most important destination for sewage sludge is in agriculture since it is rich in nutrients and, consequently, an excellent organic fertilizer (Contin et al., 2012). Sewage sludge has high contents of organic matter and nitrogen, as well as other minerals of agronomic interest (Lima et al., 2011). The use of sewage sludge and its potential for use as fertilizer and soil conditioner represent the possibility of reducing the use of mineral fertilizers and increasing crop productivity (Guedes et al., 2006), as long as it is used according to appropriate procedures to minimize environmental and ecological impact (Usman et al., 2012). Sewage sludge improves soil fertility by increasing cation exchange capacity (CEC) when incorporated into soil, reducing concentrations of exchangeable aluminum and increasing soil microbial activity, as well as improving its physical and biological attributes. It is also a source of macro- and micronutrients for plants (Prado and
Cunha, 2011). In contrast, sewage sludge contains high amounts of heavy metals that can cause environmental damage, polluting the soil and groundwater and presenting toxicity to plants (Bettiol and Ghini, 2011). Use of the parameters and procedures defined in Resolution 375/2006 of CONAMA - National Environment Council (CONAMA, 2006) for sewage sludge should be considered.

Eucalyptus forest plantations are economically and ecologically important in Brazil, producing several products and raw materials, mostly for the timber and cellulose industry, and contributing to deforestation reduction owing to the replacement of wood from native forests for those of cultivated forests (Moreira et al., 2017). The production cycle of the crop is long, requiring the application of slow release fertilizers because the soils used for forest plantations are usually poor in nutrients (Ibrahim et al., 2019). Several studies have been carried out with the use of sewage sludge in forest plantations;

\footnotetext{
*Corresponding author:

Armando Reis Tavares, Instituto Agronômico de Campinas, Avenida Luiz Pereira dos Santos, 1.500, CEP 13214-820, Jundiai, SP, Brazil.

E-mail: atavares2005@yahoo.com.br

Received: 01 August 2019; $\quad$ Accepted: 30 December 2019
} 
however, further studies are needed to understand its effects on soil and plants (Zabotto et al., 2018).

The objective of our study was to gain insight into the effects of the application of sewage sludge on the growth, physiology and nutrition of hybrid Eucalyptus urograndis (Eucalyptus grandis $\mathrm{x}$ E. urophylla) seedlings submitted to different doses of sewage sludge in soil.

\section{MATERIAL AND METHODS}

The experiment was conducted in São Paulo (2330'S and $46^{\circ} 40^{\prime} \mathrm{W}$ ), State of São Paulo, Brazil, located at $770 \mathrm{~m}$ above sea level. The experiment was carried out in a greenhouse and it was diary watered. The analysis of irrigation water showed pH - 7.7; K - 0.07 mM; Ca - 0.320 mM; $\mathrm{Mg}-0.060$ mM; $\mathrm{Cl}-0.960 \mathrm{mM} ; \mathrm{Na}-0.100 \mathrm{mM} ; \mathrm{CO}_{3}-0.000 \mathrm{mM}$; $\mathrm{HCO}_{3}^{-}-0.420 \mathrm{mM}$; SAR (Sodium Absorption Ratio) - 0.23 and EC - $0.080 \mathrm{dS} \mathrm{m}^{-1}$.

The hybrid Eucalyptus urograndis (Eucalyptus grandis $\mathrm{x}$ E. urophylla) seedlings were obtained from cuttings of a commercial producer. Six-month-old plants $(0.41 \mathrm{~cm}$ height, $3.01 \mathrm{~mm}$ stem diameter, $3.61 \mathrm{~g}$ fresh leaf mass, $2.18 \mathrm{~g}$ fresh stem mass and $2.26 \mathrm{~g}$ fresh root mass, $1.24 \mathrm{~g}$ leaf dry mass, $0.80 \mathrm{~g}$ stem dry mass and root dry mass $0.77 \mathrm{~g}$ ) were transplanted into $14 \mathrm{~L}$ polyethylene pots.

The sewage sludge (Table 1) was obtained from a sewage treatment plant (ETE) located in Botucatu, São Paulo State, Brazil, where it underwent the composting process. The sewage sludge remained in the drying bay for about 70 days, presenting temperatures above $55^{\circ} \mathrm{C}$, which permitted the disinfection (according to CONAMA Resolution No. 375/2006) and drying of the material (20\% humidity). The soil used was dystrophic Red-Yellow Latosol (LVA) soil from the forest area (Table 2). It was collected at depths of $20 \mathrm{~cm}$ and sieved in a $2 \mathrm{~cm}$ mesh. The soil was incorporated with $2 \mathrm{Mg} \mathrm{ha}^{-1}$ of agricultural limestone (PRNT 92\%) for pH correction (Raij et al. 1996).

The treatments were Soil (dystrophic Red-Yellow Latosol (LVA) soil) - Control; $30 \mathrm{Mg} \mathrm{ha}{ }^{-1}$ sewage sludge + Soil;
$60 \mathrm{Mg} \mathrm{ha}^{-1}$ sewage sludge + Soil or $90 \mathrm{Mg} \mathrm{ha}^{-1}$ sewage sludge + Soil. After 150 days of experimentation (Fig. 1), three seedlings from each treatment were randomly selected and analyzed for relative chlorophyll content using SPAD-502 ${ }^{\circledR}$ portable equipment (Minolta, Osaka, Japan). The analysis of chlorophyll $a$ and $b$, in addition to carotenoid contents in leaves, was performed according to Lee et al. (1987). Chlorophyll $a$ fluorescence (MultiMode Chlorophyll Fluorometer OS5p ${ }^{\circledR}$, Opti-Sciences, Hudson, USA) and gas exchange (Infrared Gas Analyzer LCpro $^{+}$, ADC BioScientific Ltd. Global House, Hertfordshire, UK) were evaluated as described by Silva et al. (2017). The plants were sectioned into leaves, stems and roots and weighed to obtain fresh mass. Dry mass was obtained after drying in a forced air oven at $65^{\circ} \mathrm{C}$ until constant weight. The ratio of root and shoot dry matter (R/S) was calculated. Chemical analyses of the leaves and soil were carried out in the Laboratory of Mineral Nutrition in Plants at UNESP, Botucatu, São Paulo State, Brazil.

The experimental design was a randomized block design with four treatments and three blocks with four plants per replication. Data were analyzed by variance analysis (ANOVA) and the means compared by Tukey's test $(p \leq 0.05)$, using the Sisvar 5.3 Statistical Software.

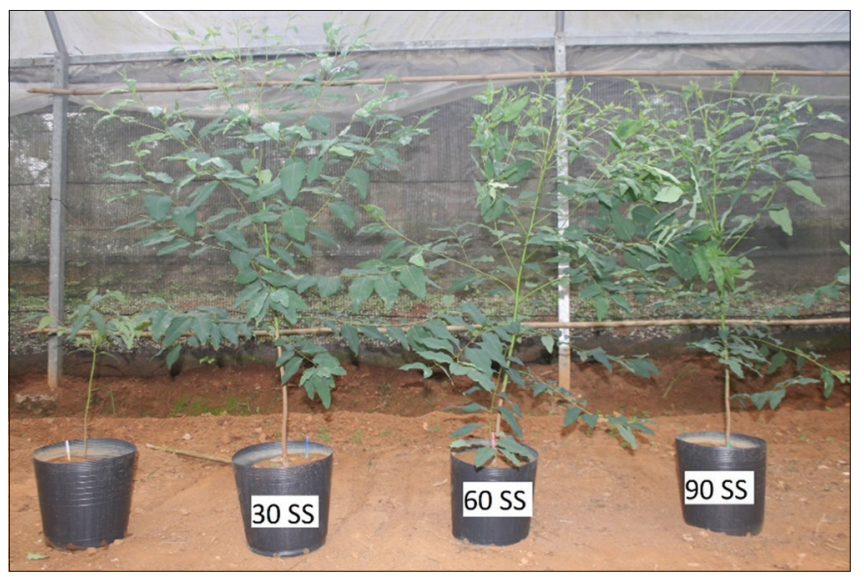

Fig 1. Hybrid Eucalyptus urograndis sfter 150 days of experimentation submitted to treatments Soil (dystrophic Red-Yellow Latosol - LVA) - Control; $30 \mathrm{Mg} \mathrm{ha}^{-1}$ sewage sludge (SS) + Soil; $60 \mathrm{Mg} \mathrm{ha}^{-1}$ sewage sludge (SS) + Soil or $90 \mathrm{Mg} \mathrm{ha}^{-1}$ sewage sludge (SS) + Soil.

Table 1: Chemical composition of dystrophic Red-Yellow Latosol (LVA) soil

\begin{tabular}{|c|c|c|c|c|c|c|c|c|c|c|c|c|c|c|c|c|}
\hline $\mathrm{pH}$ & O.M. & $\mathbf{P}_{\text {resine }}$ & $\mathrm{Al}^{3+}$ & $\mathrm{H}+\mathrm{Al}$ & $\mathrm{Na}$ & $\mathrm{K}$ & $\mathrm{Ca}$ & $\mathrm{Mg}$ & CEC & BS & S & B & $\mathrm{Cu}$ & $\mathrm{Fe}$ & Mn & $\mathrm{Zn}$ \\
\hline $\mathrm{CaCl}_{2}$ & $\mathrm{~g} \mathrm{dm}^{-3}$ & $\mathrm{mg} \mathrm{dm}^{-3}$ & \multicolumn{7}{|c|}{$\mathrm{mmol}_{\mathrm{c}} \mathrm{dm}^{-3}$} & $\%$ & \multicolumn{6}{|c|}{$\mathrm{mg} \mathrm{dm}^{-3}$} \\
\hline 3.8 & 15 & 2 & 23 & 106 & - & 0.2 & 4 & 1 & 111 & 5 & 105.8 & 0.5 & 0.5 & 43.7 & 0.2 & 0.57 \\
\hline
\end{tabular}

Table 2: Chemical composition of sewage sludge

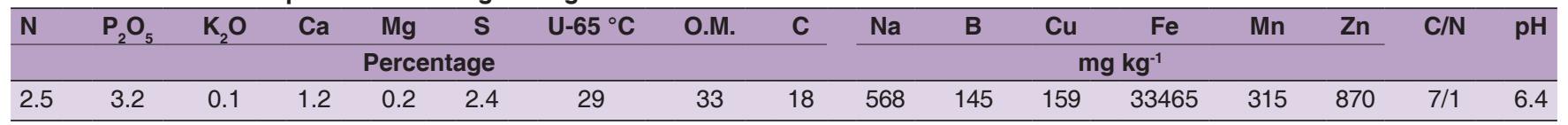




\section{RESULTS AND DISCUSSION}

Organic matter (O.M.) of the soil increased 59\% with the application of 30,60 or $90 \mathrm{Mg} \mathrm{ha}^{-1}$ of sewage sludge when compared to the control treatment. Sewage sludge is rich in organic matter and a source of $\mathrm{N}, \mathrm{P}$ and $\mathrm{S}$, and it is fundamental to the availability of plant nutrients (Cunha et al., 2016). O.M. in soil can also form aggregates, increasing its stability and reducing erosive potential (Galdos et al., 2009). The capacity of cation exchange (CEC) increased as the doses of sewage sludge increased in treatments. Soils with higher CEC can maintain adequate quantities of $\mathrm{Ca}^{2+}, \mathrm{Mg}^{2+}$ and $\mathrm{K}^{+}$than soils with low CEC; however this soils can retain acid cations such as hydrogen $\left(\mathrm{H}^{+}\right)$and aluminum $\left(\mathrm{Al}^{3+}\right)$ (Ross and Ketterings, 2011).

The application of sewage sludge did not alter the $\mathrm{pH}$ of the soils, allowing them to remain in the range suitable for the growth of the species, which is usually adapted to and cultivated in acidic soils. The increase in $\mathrm{pH}$ in degraded areas after application of sewage sludge results from the lime $(\mathrm{CaO})$ used to treat the residue (Ricci et al., 2010). The application of 30,60 and $90 \mathrm{Mg} \mathrm{ha}^{-1}$ sewage sludge added $750,1,500$ and $2,250 \mathrm{~kg} \mathrm{ha}^{-1} \mathrm{~N}$ to the soil, respectively. The treatments with sewage sludge also increased $\mathrm{P}$ contents in soil (Table 3). Phosphorus has been a finite resource and extremely important for the maintenance of agricultural productivity (Pantano et al., 2016); consequently, the use of sewage sludge is a sustainable way to provide this element to plants, allowing its recycling and minimizing the need to exploit this resource (Guimarães et al., 2018). Sewage sludge can partially replace phosphate mineral fertilizers in corn crops, obtaining results equivalent to those reached by traditional inorganic fertilizers (Bártolo et al., 2017). Ca and Mg contents were not modified by treatments; however, the values were shown to be sufficient for the initial development of the culture, maintaining BS (Base Sum) close to $25 \%$, which is suggested by several authors as ideal for the development of eucalyptus species. The micronutrients $\mathrm{B}, \mathrm{Cu}, \mathrm{Fe}, \mathrm{Mn}$ and $\mathrm{Zn}$ were below the content levels acceptable for use in forest plantations; thus, not reaching levels of soil contamination (CETESB, 2005).

The results of foliar analyses (Table 4) show a deficiency of $\mathrm{K}$ in all treatments (Gonçalves et al., 1997) with marginal chlorosis in older leaves after 60 days of planting, a symptom of deficient $\mathrm{K}$ in Eucalyptus (Silveira et al., 2005). Sewage sludge is nutritionally unbalanced, as for example $\mathrm{K}$, which is trapped in water during the process of sewage sludge separation at the sewage treatment plant (Oliveira et al., 2010). N contents in the leaves increased with higher sewage sludge doses, ranging from 14 to $35 \mathrm{~g} \mathrm{~kg}^{-1}$. N concentrations in the leaves of control treatment were also within the range of recommended $\mathrm{N}$ for adult Eucalyptus plants (Gonçalves et al., 1997), showing the efficient uptake and use of this nutrient in this species. $P$ concentrations in leaves with treatments of 30,60 and 90 $\mathrm{Mg} \mathrm{ha}{ }^{-1}$ sewage sludge were adequate (1.0 to $1.3 \mathrm{mg} \mathrm{kg}^{-1}$ ) for Eucalyptus (Gonçalves, 2015), while those of control treatment were lower. $\mathrm{Ca}$ and $\mathrm{Mg}$ contents were comparable to the contents in leaves of Eucalyptus urophylla $\mathrm{x}$ Eucalyptus globulus adult plants (Vieira et al., 2013), but lower than those in leaves of hybrid Eucalyptus urograndis seedlings (10.1 to $12.7 \mathrm{~g} \mathrm{~kg}^{-1} \mathrm{Ca}, 3.1$ to $3.9 \mathrm{~g} \mathrm{~kg}^{-1} \mathrm{Mg}$ ) (Melo Silva et al., 2018). $\mathrm{S}$ contents in leaves of plants treated with sewage sludge were higher than those reported by Viera et al. (2012) in hybrid Eucalyptus urograndis adult trees $\left(1.05 \mathrm{mg} \mathrm{kg}^{-1}\right)$. Leaf contents of B were lower than those recommended for Eucalyptus plants (Gonçalves et al., 1997). B can limit Eucalyptus productivity (Gonçalves et al., 2015), and its deficiency can be visually distinguished by the drought of the apical meristem, followed by loss of dominance (Ferreto et al., 2016), which was not observed in this experiment. The control treatment had lower Fe contents than the recommended levels (Gonçalves et al., 1997). Treatments of 60 and $90 \mathrm{Mg} \mathrm{ha}^{-1}$ sewage sludge exhibited

Table 3: Chemical composition of soil treated with sewage sludge after 150 days of experimentation

\begin{tabular}{|c|c|c|c|c|c|c|c|c|c|c|c|c|c|c|c|c|}
\hline \multirow{2}{*}{$\begin{array}{l}\text { Sewage sludge } \\
\left(\mathrm{Mg} \mathrm{ha}^{-1}\right)\end{array}$} & \multirow{2}{*}{$\begin{array}{c}\mathrm{pH} \\
\mathrm{CaCl}_{2}\end{array}$} & \multirow{2}{*}{$\frac{\mathrm{OM}}{\mathrm{g} \mathrm{dm}^{-3}}$} & \multirow{2}{*}{$\begin{array}{c}P_{\text {resine }} \\
\mathrm{mg} \mathrm{dm}^{-3}\end{array}$} & $\mathrm{Al}^{3+}$ & $\mathrm{H}+\mathrm{Al}$ & K & $\mathrm{Ca}$ & Mg & BS & CEC & $\mathrm{s}$ & B & $\mathrm{Cu}$ & $\mathrm{Fe}$ & Mn & $\mathrm{Zn}$ \\
\hline & & & & \multicolumn{7}{|c|}{$\mathrm{mmol}_{\mathrm{c}} \mathrm{dm}^{-3}(\%)$} & \multicolumn{6}{|c|}{$\mathrm{mg} \mathrm{dm}^{-3}$} \\
\hline 0 & 4.2 & 12 & 2 & 6 & 54 & 0.4 & 10 & 7 & 17 & 71 & 120.7 & 0.3 & 0.7 & 59.9 & 0.2 & 2.3 \\
\hline 30 & 4.1 & 19 & 24 & 11 & 66 & 0.5 & 17 & 7 & 25 & 91 & 166.5 & 0.3 & 1.1 & 86.4 & 0.4 & 5.6 \\
\hline 60 & 3.9 & 19 & 46 & 15 & 85 & 0.2 & 17 & 7 & 25 & 110 & 270.1 & 0.4 & 1.3 & 116.4 & 1.2 & 9.7 \\
\hline 90 & 4.1 & 19 & 76 & 12 & 87 & 0.3 & 37 & 13 & 51 & 138 & 284.1 & 0.4 & 1.6 & 135.5 & 1.4 & 14.2 \\
\hline
\end{tabular}

Table 4: Chemical analyses of hybrid Eucalyptus urograndis leaves

\begin{tabular}{|c|c|c|c|c|c|c|c|c|c|c|c|}
\hline \multirow[t]{2}{*}{ Sewage sludge $\left(M^{\prime g h a-1}\right)$} & $\mathbf{N}$ & $\mathbf{P}$ & $\mathbf{K}$ & $\mathrm{Ca}$ & $\mathrm{Mg}$ & S & B & $\mathrm{Cu}$ & $\mathrm{Fe}$ & Mn & $\mathrm{Zn}$ \\
\hline & \multicolumn{6}{|c|}{$\mathrm{g} \mathrm{kg}^{-1}$} & \multicolumn{5}{|c|}{$\mathrm{mg} \mathrm{kg}^{-1}$} \\
\hline 0 & 14 & 0.3 & 4 & 7 & 2.6 & 1.4 & 23 & 4 & 57 & 199 & 30 \\
\hline 30 & 31 & 1.3 & 6 & 6 & 2.8 & 2.9 & 25 & 13 & 370 & 477 & 60 \\
\hline 60 & 32 & 1.2 & 7 & 6 & 2.9 & 2.4 & 22 & 13 & 111 & 852 & 71 \\
\hline 90 & 35 & 1.4 & 6 & 6 & 2.8 & 2.8 & 28 & 13 & 129 & 822 & 85 \\
\hline
\end{tabular}


values within the recommended range for Eucalyptus crop (150 - $\left.200 \mathrm{mg} \mathrm{kg}^{-1}\right)$, while plants treated with $30 \mathrm{Mg} \mathrm{ha}^{-1}$ sewage sludge presented higher $\mathrm{Fe}$ contents.

Sewage sludge application increased plant height (Table 5) when compared to the control treatment $(\mathrm{p} \leq 0.05)$. Treatment with $30 \mathrm{Mg} \mathrm{ha}^{-1}$ sewage sludge resulted in plants with larger diameter of the stem than other treatments $(p \leq 0.05)$. Both fresh and dry mass of leaves, stem and total (roots + stem + leaves) of plants in treatments of 30 , 60 and $90 \mathrm{Mg} \mathrm{ha}^{-1}$ sewage sludge were higher $(\mathrm{p} \leq 0.05)$ compared to control $\left(0 \mathrm{Mg} \mathrm{ha}{ }^{-1}\right.$ sewage sludge). Plants fertilized with $30 \mathrm{Mg} \mathrm{ha}^{-1}$ sewage sludge presented higher fresh root mass than control treatment, and treatments of 60 and $90 \mathrm{Mg} \mathrm{ha}^{-1}$ sewage sludge resulted in greater root dry mass than control, and $90 \mathrm{Mg} \mathrm{ha}^{-1}$ sewage sludge treatments. Both fresh and dry mass of plants treated with 30, 60, and $90 \mathrm{Mg} \mathrm{ha}^{-1}$ sewage sludge were higher than the control. Plants treated with $30 \mathrm{Mg} \mathrm{ha}^{-1}$ sewage sludge showed 270\% higher yield for fresh mass and 231\% for dry mass in relation to control (0 Mg ha ${ }^{-1}$ sewage sludge). The results of biomass, height and diameter of the stem of hybrid Eucalyptus urograndis are directly related to chemical analysis of soil and leaves that showed the nutritional effect of sewage sludge with increases of macro and micronutrient contents in the soil and, hence, plant uptake. E. camaldulensis was $20 \%$ taller and had $40 \%$ more leaves than control, showing the excellent fertilization properties of soil/sludge (40/60) mixture (Leila et al., 2017). Plants treated with $30 \mathrm{Mg} \mathrm{ha}^{-1}$ sewage sludge showed fresh and dry root mass greater than treatments of 60 and $90 \mathrm{Mg} \mathrm{ha}^{-1}$ sewage sludge, demonstrating that high doses of sewage sludge can inhibit root growth. This effect may be related to the high levels of heavy metals in sewage sludge, e.g., $12 \mathrm{mg} \mathrm{dm}^{-3} \mathrm{Fe}, 1.2 \mathrm{mg} \mathrm{dm}^{-3} \mathrm{Zn}$ and $10 \mathrm{mg} \mathrm{dm}^{-3} \mathrm{P}$, all considered high for this crop (Raij et al., 1996). Eucalyptus urophylla seedlings showed inhibition of root and shoot growth with increasing doses of $\mathrm{Zn}$ in nutrient solution $\left(0,2,50,150,300\right.$ or $450 \mu \mathrm{mol} \mathrm{L}-1$ as $\mathrm{ZnSO}_{4} .7 \mathrm{H}_{2} \mathrm{O}$ ) (Ramos et al., 2009). The control treatment $\left(0 \mathrm{Mg} \mathrm{ha}^{-1}\right.$ sewage sludge) presented a higher relationship between shoot and root dry mass, possibly reflecting a strategy for this plant when availability of nutrients in the soil is low; in this case, the greatest root expansion occurs in order to uptake the maximum nutrients in this condition (Edwards, 2004).

Soil-plant analysis development (SPAD) values for plants treated with 60 and $90 \mathrm{Mg} \mathrm{ha}^{-1}$ sewage sludge were higher than control treatments (0) and $30 \mathrm{Mg} \mathrm{ha}{ }^{-1}$ sewage sludge (Table 6). Visually, the leaves of plants on sewage sludge treatments showed intense green coloration, while plants of control treatment $\left(0 \mathrm{Mg} \mathrm{ha}^{-1}\right.$ sewage sludge $)$ showed reddish leaves, confirming the SPAD readings. $\mathrm{N}$ contents of leaves and SPAD values for Eucalyptus globulus are directly related, making the technique helpful for management of $\mathrm{N}$ in Eucalyptus plants up to two years old (Madeira et al., 2009). The noncorrelation between SPAD readings and chlorophyll content in our experiment could be explained by the fact that $\mathrm{N}$ in leaves is not associated with chlorophyll molecules (Duru, 2002). Since SPAD meters cannot identify $\mathrm{N}$ not incorporated into chlorophyll molecules (luxury consumption), no change in the intensity of green coloration will be reflected (Mascarello et al., 2016).

Plants treated with $60 \mathrm{Mg} \mathrm{ha}^{-1}$ sewage sludge presented higher photochemical efficiency $(\mathrm{Fv} / \mathrm{Fm})$ in relation to control $(\mathrm{p} \leq 0.05) . \mathrm{Fv} / \mathrm{Fm}$ values between 0.75 and 0.85 are ideal in healthy plants; however, it is important to

Table 5: Height, stem diameter (SD), fresh leaf mass (FLM), fresh stem mass (FSM), fresh root mass (FRM), total fresh mass (TFM), dry leaf mass (DLM), dry stem mass (DSM), dry root mass (DRM), total dry mass (TDM) and root dry mass/shoot dry mass ratio (R/S) of hybrid Eucalyptus urograndis plants under sewage sludge treatments. Means followed by the same letter do not differ by Tukey's test $(p \geq 0.05)$

\begin{tabular}{|c|c|c|c|c|c|c|c|c|c|c|c|}
\hline \multirow{2}{*}{$\begin{array}{l}\text { Sewage sludge } \\
\left(M h^{-1}\right)\end{array}$} & \multirow{2}{*}{$\begin{array}{l}\text { Height } \\
(\mathrm{m})\end{array}$} & \multirow{2}{*}{$\begin{array}{c}\text { SD } \\
(\mathrm{mm})\end{array}$} & FLM & FSM & FRM & TFM & DLM & DSM & DRM & TDM & \multirow[t]{2}{*}{$\mathrm{R} / \mathrm{S}$} \\
\hline & & & \multicolumn{8}{|c|}{ g } & \\
\hline 0 & $0.74^{\mathrm{B}}$ & $8.50^{C}$ & $39.12^{\mathrm{B}}$ & $37.18^{\mathrm{B}}$ & $37.73^{C}$ & $114.04^{B}$ & $14.69^{\mathrm{B}}$ & $14.63^{B}$ & $14.36^{\mathrm{B}}$ & $43.70^{B}$ & 0.49 \\
\hline 30 & $1.21^{\mathrm{A}}$ & $11.55^{\mathrm{A}}$ & $119.81^{\mathrm{A}}$ & $126.32^{A}$ & $62.41^{A}$ & $308.55^{A}$ & $38.42^{\mathrm{A}}$ & $42.60^{A}$ & $20.01^{A}$ & $101.04^{\mathrm{A}}$ & 0.25 \\
\hline 60 & $1.15^{\mathrm{A}}$ & $10.22^{\mathrm{B}}$ & $123.40^{\mathrm{A}}$ & $120.00^{A}$ & $54.59^{\mathrm{BC}}$ & $298.00^{A}$ & $37.55^{\mathrm{A}}$ & $40.61^{\mathrm{A}}$ & $17.23^{\mathrm{AB}}$ & $95.40^{A}$ & 0.22 \\
\hline 90 & $1.19^{A}$ & $10.19^{B}$ & $121.96^{A}$ & $117.62^{A}$ & $46.39^{B}$ & $285.97^{A}$ & $38.03^{A}$ & $39.46^{\mathrm{A}}$ & $13.39^{B}$ & $90.89^{A}$ & 0.17 \\
\hline
\end{tabular}

Table 6: Relative content of chlorophyll (SPAD), chlorophyll a, chlorophyll b, carotenoids, total chlorophyll, photochemical efficiency $(\mathrm{Fv} / \mathrm{Fm})$, liquid photosynthesis $(A)$, stomatal conductance $(G s)$ and transpiration $(E)$ of hybrid Eucalyptus urograndis under sewage sludge treatments. Means followed by the same letter do not differ by Tukey's test $(p>0.05)$

\begin{tabular}{|c|c|c|c|c|c|c|c|c|c|}
\hline \multirow{2}{*}{$\begin{array}{l}\text { Sewage sludge } \\
\left(\mathrm{Mg} \mathrm{ha}^{-1}\right)\end{array}$} & \multirow[t]{2}{*}{ SPAD } & Chl a & Chl $b$ & Carot & Total chl & \multirow[t]{2}{*}{ Fv/Fm } & \multirow[t]{2}{*}{$A \mu \mathrm{mol} \mathrm{m} \mathrm{m}^{-2} \mathrm{~s}^{-1}$} & \multirow[t]{2}{*}{ Gs $\mathrm{mol} \mathrm{H}_{2} \mathrm{O} \mathrm{m}^{-2} \mathrm{~s}^{-1}$} & \multirow[t]{2}{*}{$E \mathrm{~mol} \mathrm{H}_{2} \mathrm{O} \mathrm{m}^{-2} \mathrm{~s}^{-1}$} \\
\hline & & \multicolumn{4}{|c|}{$\mathrm{mg} \mathrm{cm}^{-2}$} & & & & \\
\hline 0 & $34.09^{c}$ & $2.99^{B}$ & $5.20^{A}$ & $0.68^{\mathrm{B}}$ & $8.20^{A}$ & $0.49^{\mathrm{B}}$ & $5.68^{c}$ & $0.38^{\mathrm{C}}$ & $2.89^{B}$ \\
\hline 30 & $41.24^{\mathrm{B}}$ & $3.93^{\mathrm{A}}$ & $5.25^{A}$ & $1.05^{\mathrm{A}}$ & $9.19^{A}$ & $0.57^{\mathrm{AB}}$ & $12.70^{\mathrm{B}}$ & $0.69^{B}$ & $4.18^{\mathrm{A}}$ \\
\hline 60 & $44.24^{\mathrm{A}}$ & $3.73^{\mathrm{AB}}$ & $6.46^{A}$ & $0.86^{\mathrm{AB}}$ & $10.20^{\mathrm{A}}$ & $0.58^{A}$ & $14.67^{A}$ & $0.92^{\mathrm{A}}$ & $4.19^{A}$ \\
\hline 90 & $44.90^{A}$ & $3.20^{A B}$ & $5.70^{\mathrm{A}}$ & $0.72^{\mathrm{B}}$ & $8.91^{A}$ & $0.55^{\mathrm{AB}}$ & $14.92^{A}$ & $0.98^{A}$ & $4.21^{\mathrm{A}}$ \\
\hline
\end{tabular}


note that these values may vary, or be underestimated, for each species owing to climatic conditions, such as low or high temperatures, or cultivation method (Björkman and Demmig, 1987). Nutrient supply to plants increases the photochemical efficiency in the reaction centers when exposed to light. For example, Pinus radiata showed increasing Fv/ Fm values with the elevation of $\mathrm{N}$ fertilization (Bown et al., 2009). On the other hand, Ochroma pyramidale showed a considerable reduction in photochemical efficiency in the absence of P (Cunha et al., 2016).

Plants treated with 60 and $90 \mathrm{Mg} \mathrm{ha}^{-1}$ sewage sludge showed higher photosynthetic rates $(A)$ with 14.67 and $14.92 \mu \mathrm{mol} \mathrm{CO} \mathrm{m}^{-2} \mathrm{~s}^{-1}$ and higher stomatal conductance (Gs) with 0.92 and $0.98 \mathrm{mmol} \mathrm{H}_{2} \mathrm{O} \mathrm{m}^{-2} \mathrm{~s}^{-1}$, respectively. Meanwhile, control had the lowest values $(5.68 \mu \mathrm{mol}$ $\mathrm{CO}_{2} \mathrm{~m}^{-2} \mathrm{~s}^{-1}$ and $\left.0.38 \mathrm{mmol} \mathrm{H}_{2} \mathrm{O} \mathrm{m}^{-2} \mathrm{~s}^{-1}\right)$. Photosynthetic rate is one of the factors responsible for the higher productivity of Eucalyptus with a linear relationship between maximum photosynthesis and productivity (Otto et al., 2013). Values are equivalent to the photosynthetic rates of Eucalyptus plants submitted to water deficit (1.2 to $3.4 \mu \mathrm{mol} \mathrm{CO} \mathrm{m}^{-2} \mathrm{~s}^{-1}$ ) and water availability (12.5 to $16.4 \mu \mathrm{mol} \mathrm{CO} \mathrm{m}^{-2} \mathrm{~s}^{-1}$ ) (Otto et al., 2013), showing that nutritional deficiency in Eucalyptus can be as limiting to photosynthesis and, consequently, to productivity as water deficiency. The transpiration rate (E) was higher in plants fertilized with 30,60 or $90 \mathrm{Mg} \mathrm{ha}^{-1}$ sewage sludge.

\section{CONCLUSION}

Our results indicated that sewage sludge increase soil fertility by augment of N, P and O.M. contents and CEC in soil. The application of $60 \mathrm{Mg} \mathrm{ha}^{-1}$ sewage sludge in the soil provided higher values of growth and development variables and positively impacted the physiological variables studied in hybrid E. urograndis. However, $90 \mathrm{Mg} \mathrm{ha}^{-1}$ sewage sludge inhibited hybrid E. urograndis root growth.

\section{Author's contributions}

All authors contributed equally to the production of the manuscript.

\section{Declaration of conflicting interests}

The authors declared no potential conflicts of interest with respect to the research, authorship, and/or publication of this article.

\section{Funding}

The study was supported by Fundação de Apoio à Pesquisa (FAPESP - Research Partnership for Technological Innovation - PITE, 13/50413-0) and Productivity Grants from the Brazilian National Research Council (CNPq).

\section{REFERENCES}

Bártolo, I., R. Fernandes and C. Sempiterno. 2017. Valorização agrícola de lamas: Disponibilidade do fósforo. Rev. Ciênc. Agrár. 40: 497-505.

Bettiol, W. and R. Ghini 2011. Impacts of sewage sludge in tropical soil: A case study in Brazil. Appl. Environ. Soil Sci. 2011: 11.

Björkman, O. and B. Demmig. 1987. Photon yield of $\mathrm{O}_{2}$ evolution and chlorophyll fluorescence characteristics at $77 \mathrm{~K}$ among vascular plants of diverse origins. Planta. 170: 489-504.

Bown, H. E., E. G. Mason, P. W. Clinton and M. S. Watt. 2009. Chlorophyll fluorescence response of Pinus radiata clones to nitrogen and phosphorus supply. Cienc. Invest. Agric. 36: 451-464.

CETESB. 2005. Dispõe sobre a aprovação dos Valores Orientadores para Solos e Águas Subterrâneas no Estado de São Paulo-2005, em substituição aos Valores Orientadores de 2001, e dá outras providências. CETESB, São Paulo, Brazil.

CONAMA. 2006-Ministério do Meio Ambiente, Conselho Nacional de Meio Ambiente, CONAMA. Resolução CONAMA n 375/2006, de 30 de agosto de 2006-In: Resoluções, 2006. CONAMA, Brasília, Brazil.

Contin, M., D. Goi and M. de Nobili. 2012. Land application of aerobic sewage sludge does not impair methane oxidation rates of soils. Sci. Total Environ. 441: 10-18.

Cunha, H. F. V., J. D. C. Gonçalves, J. Santos, M. J. Ferreira and P. H. P. Peixoto. 2016. Biomass, gas exchange and nutritional aspects of young plants of balsa wood (Ochroma pyramidale (Cav. ex Lamb.) Urb.) subjected to phosphorus fertilization in contrasting irradiance environments. Sci. Forest. 44: 215-230.

Duru, M. 2002. Evaluation of chlorophyll meter to asses nitrogen status of cocksfoot Sward. J. Plant Nutr. 25: 275-286.

Edwards, C. A (Ed.). 2004. The use of earthworms in the breakdown and management of organic wastes. In: Earthworm Ecology. St. Lucie Press, Boca Raton.

Ferreto, D. O. C., J. D. P. Rodrigues, M. A. Ibarr, C. S. de Oliveira, R. C. B. Vieira, M. A. Weber and F. C. B. Vieira. 2016. Boron fertilization and liming for Eucalyptus urograndis cropped on sandy arenosol of Brazilian pampa. J. Plant Nutr. 39: 399-409.

Galdos, M. V., I. C. de Maria, O. A. Camargo and S. C. F. Dechen. 2009. Sewage sludge application on cultivated soils: Effects on runoff and trace metal load. Sci. Agric. 66: 368-376.

Gonçalves, J. L. De M., B. Van Raij and J. C. Gonçalves. 1997. Florestais. In: J. L. De M. Gonçalves, B. Van Raij and J. C. Gonçalves (Eds.), Recomendações de adubação e calagem para o Estado de São Paulo. Instituto Agronômico/Fundação IAC. Campinas, Brazil.

Gonçalves, J. L. M., C. A. Alvares, A. H. B. Souza and J. C. A. Junior. 2015. Caracterização edafoclimática e manejo de solos das áreas com plantações de eucalipto. In: M. V. Schumacher and M. Viera (Eds.), Silvicultura do Eucalipto no Brasil. Ed. da Universidade Federal de Santa Maria, Santa Maria, Brazil.

Guedes, M. C., C. A. Andrade, F. Poggiani and M. E. Matiazzo. 2006. Propriedades químicas do solo e nutrição do eucalipto em função da aplicação de lodo de esgoto. Rev. Bras. Ciênc. Solo. 30: $267-280$.

Guimarães, J. C. S., J. Cordeiro and D. C. F. Vitorino. 2018. Utilização do lodo de esgoto na agricultura: uma análise cienciométrica. Res. Soc. Develop. 7: 1-31, e479391.

Ibrahim, J. F. D., I. V. da Silva Junior, F. da Costa Barros, D. R. M. Paez, A. L. Nascentes and L. D. B. da Silva. 2019. Utilização do lodo de esgoto na produção de mudas e no cultivo do eucalipto (Eucalyptus spp). Braz. J. An. Environ. Res. 2: 564-579. 
Lee, D. W., S. Bremmeier and A. P. Smith. 1987. The selective advantage of anthocyanins in developing leaves of mango and cacao. Biotropica. 19: 40-49.

Leila, S., M. Mhamed, H. Hermann, K. Mykola, W. Oliver, M. Christin, E. Onyshchenkoc and B. Nadia. 2017. Fertilization value of municipal sewage sludge for Eucalyptus camaldulensis plants. Biotech. Rep. 13: 8-12.

Lima, M. F., C. N. Mattos, P. L. C. Vieira and L. F. Almeida. 2011. Geração de lodo de esgoto e seu potencial como fonte de matéria orgânica para a agricultura. In: A. N. Costa, and A. F. S. Costa (Ed.), Manual de uso Agrícola e Disposição do Lodo de Esgoto Para o Estado do Espirito Santo. INCAPER. Vitoria, Brazil.

Madeira, A. C., M. Madeira, A. Fabião, P. Marques and M. Carneiro. 2009. Avaliação da nutrição de plantações jovens de eucalipto por análise foliar e métodos não destrutivos. Rev. Ciênc. Agr. 32: 139-153.

Mascarello, A. C., T. R. B. da Silva, B. T. Gouveia, D. Bernardi, D. Secco, R. F. Santos and C. Z. Alves. 2016. Chlorophyll meter reading and total nitrogen content applied as topdressing in parts of the Crambe plant. Afr. J. Biotech. 15: 45-49.

Melo Silva, F. A., G. Margheri Nunes, J. A. Zanon, I. Amaral Guerrini and R. Barboza da Silva. 2018. Resíduo agroindustrial e lodo de esgoto como substrato para a produção de mudas de Eucalyptus urograndis. Ciênc. Florest. 28: 827-828.

Moreira, J. M. M., F. J. Simioni and E. B. de Oliveira. 2017. Importância e desempenho das florestas plantadas no contexto do agronegócio Brasileiro. Floresta. 47: 85-94.

Oliveira, G. G., I. Z. Gonçalves, J. C. Madalão, A. A. Nazário and E. F. dos Reis. 2010. Crescimento de mudas de eucalipto submetidas à aplicação de biossólidos. Rev. Ciênc. Agron. 41: 87-94.

Otto, M. S. G., A. R. Vergani, A. N. Gonçalves, A. Vrechi, S. R. Silva and Stape, J. L. 2013. Fotossíntese, condutância estomática e produtividade de clones de Eucalyptus sob diferentes condições edafoclimáticas. Rev. Árvore. 37: 431-439.

Pantano, G., G. M. Grosseli, A. A. Mozeto and P. S. Fadini. 2016. Sustentabilidade no uso do fósforo: Uma questão de segurança hídrica e alimentar. Quím. Nova. 39: 732-740.

Prado, A. K. and M. E. T. Cunha. 2011. Efeito da aplicação de lodo de esgoto e curtume nas características físico-químicas do solo e na absorção de nitrogênio por feijoeiro (Phaseolus vulgaris L.).
UNOPAR Cient. Ciênc. Exatas Tecnol. 10: 37-41.

Raij, B. V., H. Cantarella, J. A. Quaggio and A. M. C. Furlani. 1996. Recomendações de Adubação e Calagem Para o Estado de SÃO Paulo. Instituto Agronômico (Boletim Técnico, 100), Campinas, Brazil.

Ramos, S., E. M. D. Castro, S. I. D. Carmo Pinto, V. Faquin, C. D. Oliveira and G. Carvalho Pereira. 2009. Uso do silício na redução da toxidez de zinco em mudas de eucalipto. Interciencia. 34: 189-194.

Ricci, A. B., V. C. R. Padovani and D. R. Jr. Paula. 2010. Uso de lodo de esgoto estabilizado em um solo decapitado: II-atributos químicos e revegetação. Rev. Bras. Ciênc. Solo. 34: 543-551.

Ross, D. S. and Q. Ketterings. 2011. Recommended methods for determining soil cation exchange capacity. In: A. Wolf. and J. McGrath (Eds.), Recommended Soil Testing Procedures for the Northeastern United States. Northeastern Regional Publications, College Park, MD.

Silva, K. G. D., Silva, E. A. D., Ferreira, M. L., Kanashiro, S., Camargo, P. B. D. and A. R. Tavares. 2017. Gas exchange and chlorophyll a fluorescence parameters of ornamental bromeliads. Ornam. Hort. 23: 400-406.

Silveira, R. L. V., J. L. Gava and E. Malavolta. 2005. O potássio na cultura do eucalipto. In: T. Yamada. and T. L. Roberts (Eds.), Potássio na Agricultura Brasileira. POTAFOS, Piracicaba, Brazil.

Usman, K., S. Khan, S. Ghulam, M. U. Khan, N. Khan, M. A. Khan and S. K. Khalil. 2012. Sewage sludge: An important biological resource for sustainable agriculture and its environmental implications. Am. J. Plant Sci. 3: 1708-1721.

Vieira, M., M. V. Schumacher, P. Trüby and E. F. de Araújo. 2013. Biomassa e nutrientes em um povoamento de Eucalyptus urophylla x Eucalyptus globulus, em Eldorado do Sul, RS. Rev. Ecol. Nutr. Florest. 1: 1-13.

Viera, M., D. M. Bonacina, M. V. Schumacher, F. N. Calil, M. V. W. Caldeira and L. F. Watzlawick. 2012. Biomassa e nutrientes em povoamento de Eucalyptus urograndis na serra do sudeste-RS. Semin. Cienc. Agrar. 33: 2481-2490.

Zabotto A. R., I. E. Kühn, F. Broetto, D. P. F. Oliveira, A. M. M. Ruiz, T. C. O. Andrade and E. A. Zuñiga. 2018. Lodo de esgoto: Características nutricionais e efeitos da utilização no solo. In: E. G. Ramos, E. A. Zuñiga and L. M. Machuca (Eds.), Estresse das Plantas Cultivadas and Protocolos de Análise. FEPAF, Botucatu, Brazil. 